\title{
“LAS PELEAS ENTRE EL DIABLO Y LA VIRGEN": PERMANENCIAS CULTURALES y memoria histórica entre los campesinos de Boyacá
}

\author{
CÉSAR Moreno BAPTISTA \\ Profesor de la universidad Pedagógica y Tecnológica de Colombia \\ gachaneca@hotmail.com
}

\begin{abstract}
Resumen
PARTIR DE LOS TOPÓNIMOS, LOS RELATOS ORALES Y LOS DOCUMENTOS ESCRITOS SOBRE A la localidad del desierto de La Candelaria, ubicado en el altiplano boyacense colombiano, el autor reconstruye el imaginario colectivo que en esta región pervive en torno al culto de la Virgen. "Las peleas entre el diablo y la Virgen" -como los lugareños se refieren a las luchas que dan origen a la identidad del lugar- configuran un espacio mitológico que explica la continuidad de la identidad sagrada de la localidad desde la época prehispánica hasta nuestros días.
\end{abstract}

\begin{abstract}
D LACE NAMES, oral StORIES, AND WRITTEN DOCUMENTATION ABOUT THE CANdelaria desert, located in the highland plateau of Boyacá, Colombia, serves the author to reconstruct the Virgin's worship imaginaries of this locality. "The fights between the devil and the Virgin"-as the inhabitants of the region refers to the struggles which give identity to this place- configures a mythological space that explains the continuity of a worship place since prehispanic times to the present days.
\end{abstract}




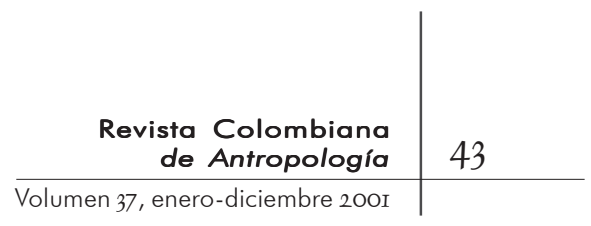

\section{INTRODUCCIÓN}

STE ARTÍCULO ANALIZA LA TRADICIÓN ORAL DE UNA PEQUEÑA REGIÓN - del departamento de Boyacá (Colombia), conocida con el nombre de desierto de La Candelaria. La reflexión quiere mostrar, de una parte, que los relatos que escuchamos hoy en día de boca de los campesinos hacen parte de la memoria histórica de la localidad y, de otra, cómo se configura un espacio simbólico a partir de las imágenes colectivas.

De acuerdo con los datos históricos, los colonizadores españoles destruyeron físicamente los santuarios muiscas y en algunos casos impusieron lugares de culto e imágenes católicas. En otros, los lugares tradicionales de adoración recibieron la bendición oficial, se erigió una iglesia, se colocó allí algún santo milagroso y con el tiempo se sustituyó el culto a lo pagano. Fue así como muchos sitios de la geografía andina que fueron puntos sagrados para los muiscas actualmente son de gran significación para los campesinos en el contexto de la tradición cristiana, pues consideran que en estos lugares habitan seres sobrenaturales.

Mi inquietud por las imágenes religiosas surge por el interés de conocer la relación que establece el campesino en Boyacá con estas imágenes, presentes en todas las actividades de la vida diaria. Esta atracción sobre el significado que el campesino le atribuye a las imágenes religiosas y que son objeto de veneración en los pueblos del departamento, ha orientado una serie de preguntas que miran hacia el pasado colonial, momento en el cual surgieron los cultos patronales.

Las imágenes de santos y cruces que colocaron los españoles en las cimas de las montañas, piedras, cuevas, etcétera, con el propósito de extirpar las idolatrías, contribuyeron a que aquellos lugares se conservaran y mantuvieran como referentes significativos en el imaginario de las comunidades colonizadas. Por esta razón, se considera que la geografía es un elemento importante en el análisis de la recreación del imaginario colectivo y las permanencias culturales.

Es de suponer que las peregrinaciones que los campesinos aún realizan año tras año para visitar las imágenes religiosas -cristos, santos, vírgenes-, son la continuidad de la costumbre que tenían los muiscas de viajar a sus santuarios naturales de Guatavita, Ubaque, Fúquene, entre otras. Ello se deduce del conjunto de 


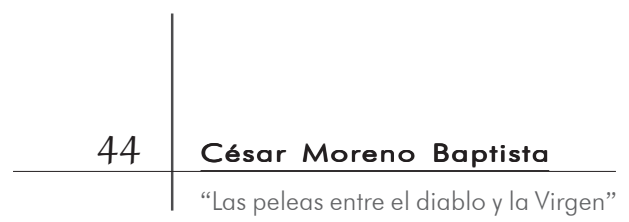

relatos de los cronistas, que describen las creencias y prácticas religiosas de los pobladores a su llegada al altiplano, y también de los relatos que se escuchan hoy en día de los campesinos.

\section{SuPERPOSICIÓN DE SANTUARIOS EN LA COLONIA}

L ESCENARIO EN EL CUAL SE RECREA LA HISTORIA DE LA TRADICIÓN ORAL - está ubicado en uno de los pequeños valles interandinos de - la vertiente occidental de la cordillera Oriental, en el altiplano central de Colombia. En el rincón sur occidental de la región conocida como el valle de Villa de Leiva se encuentra el desierto de La Candelaria. Vale la pena señalar que el topónimo desierto existe en el imaginario colectivo de los pobladores, ya que no hay una delimitación topográfica o cartográfica administrativa que permita identificarlo. Tampoco es un lugar equiparable a los grandes desiertos de África; su nombre obedece, más bien, a la soledad característica del lugar desde la época precolombina.

En la arquitectura religiosa de los siglos dieciséis y diecisiete existen, al menos, tres tipos de construcción religiosa: los conventos, las iglesias matrices y parroquiales, y los templos doctrineros. La arquitectura se diseñaba según los requerimientos de las comunidades religiosas o del clero secular, y su ubicación en el área urbana o rural.

Dentro de esta última se incluye el monasterio de La Candelaria, de tipo contemplativo, cuyo fin religioso era albergar una comunidad dedicada a la preparación de religiosos que saldrían a enseñar la doctrina cristiana. En el diseño y la construcción del convento de La Candelaria -iniciada a principios del siglo dieciséis- se empleó algo más de medio siglo para levantar los muros de la actual edificación. Según los datos históricos:

A 4 de mayo de I604 el encomendero de Tinjacá, Andrés de Veloza y Castro realizó cesión de 12 fanegadas de tierra a favor del padre Mateo, a condición de que tenga efecto la fundación de dicho convento de los Recoletos del Señor de San Agustín en la dicha ermita y casa de Nuestra Señora de La Candelaria.

En el susodicho año, ante el arzobispo de Bogotá, Bartolomé Lobo Guerrero se trasladó al dominio jurídico de la casa de el Desierto de La Candelaria con calidad y condición de que el provincial y religioso 


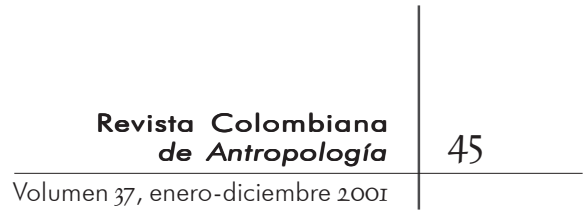

de la observancia se obligasen a hacer el convento y traer religiosos Recoletos que lo habitasen... y el padre provincial se obligó a tener la casa para frailes de la recolección y no enajenarla (Ayape, 1935: 27).

La devoción a la Virgen de La Candela o Candelaria tuvo su origen entre los marineros de las islas Canarias, quienes le encendían fuego en las embarcaciones que atravesaban los mares para que los iluminara y protegiera de los peligros.

En América, la vocación religiosa de la Virgen de La Candelaria tiene sus raíces en tradiciones populares de la edad media en las que se propagó su culto. Las grandes crisis que sufrió la iglesia occidental durante el siglo catorce, junto a una serie de calamidades como la peste negra, generaron movimientos populares que se caracterizaron por su deseo de llevar "una vida comunitaria sencilla, de abnegación e imitación a Cristo y a los apóstoles". En medio del llanto y el lamento estos fieles flagelaban sus cuerpos con gran violencia, al tiempo que invocaban a "Dios, a Cristo y a la Virgen”.

Ahora bien, la historia de la imagen de La Candelaria, como muchas otras, se enmarca dentro del proceso de colonización de los españoles en América, en el que el pensamiento occidental no aceptó las formas de creer de las culturas americanas.

Por otra parte, se relaciona con las características particulares del lugar, propicias para su culto; fue así como muchos de los ermitaños y anacoretas que llegaron del viejo continente encontraron en los parajes del nuevo mundo el lugar ideal para llevar una vida de austeridad y contemplación; Juan Rodríguez y Domingo de Anaya -dos de esos ermitaños-encontraron en el desierto de La Candelaria el sitio apropiado para adorar a la Virgen. Allí construyeron una ermita bajo la advocación de La Luz, dando inicio al culto. En otras palabras, los ermitaños fueron los gestores o inventores del culto en Colombia. En relación con los anacoretas gestores del culto Ayape dice:

En las reuniones espirituales acordaron enviar a Domingo de Anaya y Francisco de Rodríguez a Tunja y Santa Fé con el objeto de crear la erección canónica. Fue encargado en Tunja al pintor italiano Francisco del Pozo la pintura de la Virgen en la que aparece con un cirio en la mano izquierda, el niño Jesús en la mano derecha y los rostros de san José, Simeón y Ana, en la parte inferior del cuadro los rostros de santo Domingo y san Francisco. Lo escribe Flórez de Ocariz (preludio 


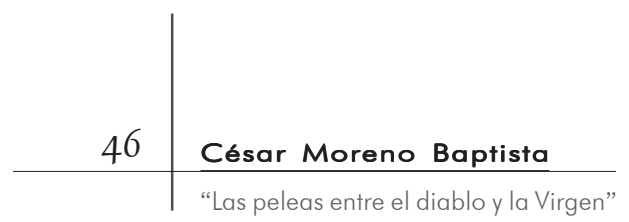

cap. 215 pp. 165): En I6 de junio de 1597 despacho y cabildo de este arzobispado de Santa Fe en sede vacante, licencia de Leyva con título Nuestra Señora de la Candelaria a petición del hermano Juan Rodríguez, por haber hecho relación que determinar dejar las cosas del mundo y apartarse a servir fuera del poblado en algún yermo para tener recogimiento y servir a Dios que era su principal intento con el hermano Diego y otros... y luego en La Candelaria, se concedió bajo la dirección del arzobispo se inicio para que fuera aprobado por el encomendero de la villa de Leyva y el vicario... habiendo conseguido el permiso cavaron los cimientos de la ermita y don Andrés Veloza y Castro les ayudó mucho (Ayape, I950).

Por otra parte, datos suministrados por John Orbell nos indican que, al iniciarse la época de la Colonia en el siglo dieciséis, la región que conocemos hoy con el nombre de Ráquira estaba habitada por cuatro grupos indígenas, y que dentro de estos el de Uranchá o Goranchá estaba situado en la vertiente del cerro de Furca, en tierras que hoy conforman el desierto de La Candelaria. En relación con el sitio donde se construyó el actual convento, Eugenio Ayape, seguramente basado en fuentes de archivo del mismo, se refiere a las prácticas rituales muiscas en el mismo lugar donde éste se construyó.

Los primeros ermitaños que vivían en miserables chozas dedicados al ejercicio de las más rigurosas austeridades en el valle de Gachaneca causaron la envidia y lasitos del infierno porque precisamente en el propio sitio donde estaban ubicados tenía el diablo un adoratorio donde recibía culto de los chibchas. Allí acudían en fervorosas y fanáticas peregrinaciones a celebrar las lunaciones de su calendario con ritos los más sacrílegos, con bailes obscenos y fiestas impúdicas... (Ayape, 1935: 187).

Más adelante dice:

No muy lejos del monasterio se levanta un montecito arisco llamado 'el volcán', por sus cónicos contornos, y las gentes dicen ser venerado, pues en su cima se halla la tumba de un cacique antiguo de esta región (Ayape, I935: 193).

Estos datos históricos, la presencia de pintura rupestre en el lugar y muchos de los relatos de tradición oral que hacen referencia a la época prehispánica nos permiten inferir -de acuerdo con la clasificación que hace Casilimas de los santuarios muiscas por 


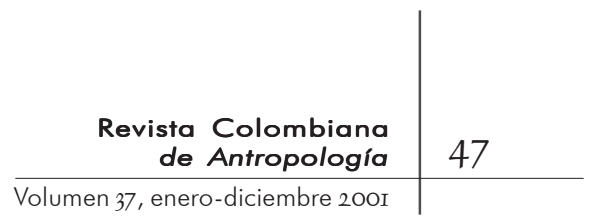

la importancia general o local de los mismos- que el actual desierto de La Candelaria puede incluirse dentro de aquellos que fueron vivienda de jeque no principal, probablemente casa de plumería o de ofrendas, cuca o seminario muisca.

\section{Iglesias y conventos}

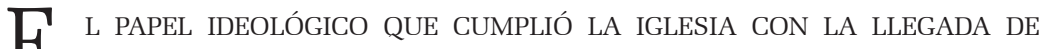
L los españoles a América fue particularmente importante en el ordenamiento territorial durante la colonia. Con la disposición de obispados, parroquias y misiones se construyó una red reguladora de poder, en la que la autoridad de la jerarquía fue ampliando la presencia de la Iglesia mediante la construcción de iglesias y conventos. Paralelamente, el proceso de socialización de los cultos patronales mediante la organización de cofradías, hermandades, etcétera, fue fundamental para dar una nueva identidad religiosa a la población conquistada.

Así es que, una vez detectado por los religiosos católicos el adoratorio muisca en el desierto, levantaron el convento para purificar el sitio, como lo justifican las constituciones sinodales.

Por cuanto los santuarios son tropiezo y estorbo para que los fieles se conviertan, y así mismo para que los nuevamente convertidos vuelvan a idolatrar, se manda que con toda solicitud y santo celo de la honra de Dios y bien de estos indios los sacerdotes inquieran dónde hay santuarios, y sabido no toquen en ellos sino den un aviso con toda brevedad a su prelado para que lo trate con el ordinario y con justicia secular para que con su autoridad se manden destruir y asolar del todo, sin que haya memoria de ellos,... y se ponga allí alguna cruz, o purificado aquel lugar se haga alguna ermita... (Groot, I893: 509).

Conforme a los relatos orales -transcritos en el archivo del convento-, el milagro se realizó con un exorcismo practicado en el lugar. Como se sabe por los archivos, éste era uno de los mecanismos empleados por la Iglesia para combatir a los chamanes que eran considerados también agentes especiales de perturbación y de mal.

Había un indio que era poseso por el demonio, él tiene su artimaña y por medio de esas artimañas el demonio lo posee y hace todas las 


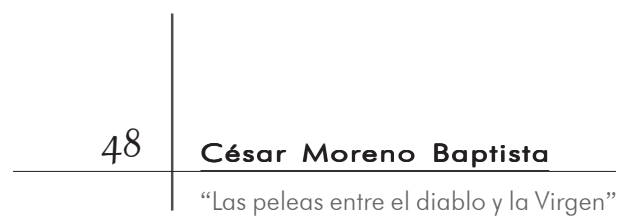

escaramuzas que quiere en base a la figura humana y así era que se valía el demonio, se valía para hacerle males al padre Mateo Delgado, hasta que lo último ya el padre lo mandó coger, una vez lo cogió con una cadena bendita y le practicó un exorcismo y ya quedó normal (Alfredo Casas).

Pero para que el acto fuera efectivo y para suprimir definitivamente los ritos gentiles, tenía mecanismos más fuertes, como desautorizar a los chamanes, amenazándolos con quemar vivo al que en adelante ejerciera tal oficio.

Los castigos para aquellos que una vez bautizados, volvieran a sus ceremonias era aparte de hecho de pecar y de incurrir en 'ira de Dios todo poderoso', la muerte de fuego y pérdida de todos los bienes, y para los que hubieran sido bautizados, en atención a que vivían entre cristianos y resultaban con sus creencias impedimento para la conversión de los demás gentiles se anunciaba la pena de horca si adoraban el demonio (Cortés, 1960: 204).

Este marco general en el que se ubica el santuario permitirá ver, de un lado, que los residentes del lugar son conscientes de su vínculo histórico con la imagen; y, de otro, que las leyendas que hoy se escuchan en el desierto, narran en general acontecimientos del origen de la imagen, tratando de explicar, en esencia, cómo se da el vínculo de ésta con la región.

Como lo señala Rapapport (2000), en la región andina cundiboyacense el orden espacial colonial reconfiguró las estructuras españolas e indígenas dentro de nuevos marcos de representación, creando de esta manera una nueva formación social.

Los españoles de la época colonial transplantaron formas memorísticas de descripción que se recrearon como temas de tradición milagrosa sobre las imágenes del panteón cristiano. En América y en Europa continuaron vigentes las leyendas medievales de hallazgos o apariciones de imágenes o de apariciones de personajes sobrenaturales. Santuarios, ermitas e iglesias contienen imágenes que dieron origen a la formación de leyendas relativas a la presencia de dichos seres en el lugar.

Estos modelos imaginativos inscritos en la tradición popular española fueron, además, sobrepuestos sobre espacios topográficos y temporales en los cuales caminaba la gente, su genealogía y su parentesco. 


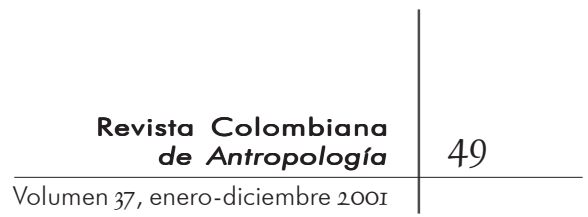

LOS RELATOS DE APARICIÓN EN EL DESIERTO DE LA CANDELARIA

C

omo lo señala Serge GruZinski (I990) EN SU CÉlebre libro LA guerra de las imágenes, la imagen religiosa es históricamente objeto de las peregrinaciones y, junto con la escritura, constituyó "uno de los principales instrumentos de la cultura europea, que en la gigantesca empresa de evangelización que se abatió sobre el continente americano adoptó -al menos en parte- la forma de una guerra de imágenes que se perpetró durante siglos y que hoy no parece de ninguna manera haber concluido".

Así, comunidades indígenas sobrevivieron al apocalipsis demográfico que los disgregó y llegaron a crearse nuevas identidades y a inventarse memorias.

Las poblaciones autóctonas "posteriormente indias, negros y españoles no se concretaron a recibir pasivamente esas imágenes, sino que les imprimieron su propio sello y llegaron a convertirlas en expresión de identidad o instrumento de rebeldía y resistencia”. En esta perspectiva, las manifestaciones culturales campesinas se conciben como la consecuencia de un proceso largo de la acción del colonizador y la reacción del colonizado que mantiene viva su identidad por medio de los imaginarios.

\section{La leyenda}

$\mathrm{D}$ E ACUERDO CON LA TRADICIÓN DEL CAMPESINO, LA VIRGEN SE APAreció en la peña llamada El calvario; entonces, el padre Mateo Delgado quiso construir una "casa a la Virgen”.

Todo comenzó cuando llegaron los primeros religiosos a evangelizar:

Se decía, creo que eso sí fue cierto, cuando el padre llegó a evangelizar aquí o tal... La Candelaria, dicen que el diablo estaba allá y el padre empezó a hacer el convento. Dicen, me lo contó mi papá, me lo contó más de uno, y el diablo hacía de noche, traía madera, traía el río crecido y le tumbaba lo que hacía en el día, el diablo lo tumbaba de noche, incluso intentaba botar el campanario, cuando el padre iba a tocar las campanas y toda la vaina y peliaban de frente, pecho a pecho, como dicen de pecho a pecho peliaban el diablo y la Virgen, se apareció 
donde el diablo estaba y lo sacó a correr de ahí y dicen que ya el diablo se arrepintió y se fue. Y ahí que cuando el diablo dejó al padre, el padre se colocó una cruz, le tuvo miedo y se fue y le dijo al padre que él se iba pero los enredos y las niguas no se acabaron, ya vino la química, algo se acabaría la plaga pero eso siempre ha existido (Ramón Veloza).

\title{
Los atentados del diablo
}

\begin{abstract}
l l verse destronado, el Diablo hizo una serie de atentados A para recuperar el lugar. Conforme a los relatos, el Pozo del diablo constituye uno de los temas más representativos de la leyenda. El Pozo del diablo se forma cerca de un recodo del río, "a un tiro de piedra" del actual convento. La tradición cuenta que era un pozo de agua de gran tamaño rodeado de vegetación, donde se aparecía el diablo para asustar a las personas. En las descripciones se le pinta como un ser horriblemente feo, con figura de persona y con cachos; también se le describe con forma de animal.
\end{abstract}

Pues el pozo del diablo según la historia dice que era un árbol de roble, que existía en la mitad del río y que entonces el demonio... arrancó la mata y que como la mata estaba en el centro que se formó el llamado pozo del diablo... (Alfredo Casas).

El tema hace parte de una cadena de episodios identificados en ciclos temáticos, los cuales presentan una serie de detalles descriptivos como nombres, personajes y objetos que enriquecen y proporcionan originalidad a las versiones.

No le digo que eso era una montaña ahí de guadua y de todo eso era ahí en el pozo, él [el diablo] tenía su rancho... (Gabriel Vargas).

Pues dicen que por ahí siempre iba el diablo que por allá vivía, por allá entre el pozo... y otros dicen que se aparecía por ahí en La Candelaria en forma de burro y con ese fue que cargaron todos los ladrillos para hacer el convento (Rocío Bautista).

El Pozo del diablo, ese es un cuento ahí de que algunas veces, algunas personas iban a bañarse y se les presentaba por ahí un mico sentado, una visión por ahí entonces lo llamaban: el Pozo del diablo (Rafael Casas). 


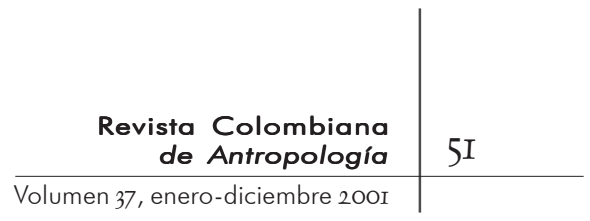

De lo que sí sé algo es que aquí este puesto era un centro de oración del diablo, era cuando los indígenas defendían el amor al diablo, por ahí está el puesto... El puesto según me contaba mi abuelita una vez, está en el centro, pero como está edificado, eso como cada uno hace una reforma a la hora de la verdad no se sabe dónde es ese sitio. Es como la madera del altar mayor, un roble que el diablo se trajo de por allá del lado de Gachaneca con el fin de destruir la iglesia (Alfredo Castillo).

Indudablemente el entendimiento que se heredó fue el del español de la colonia, que asocia toda forma de culto diferente del cristiano dentro de la categoría del mal -el diablo-. El español, heredero del pensamiento judeocristiano, creía que los demonios eran ángeles caídos, rebeldes, hostiles a Dios. Con el desarrollo de la doctrina del pecado original -la falta de Adán y Eva-, la humanidad de Cristo se percibió expuesta al dominio de Satán en el reino de las tinieblas. Precisamente la mentalidad de la época explicaría los cultos indígenas como idolatrías inspiradas por las artimañas del diablo.

\title{
La campana del diablo
}

\begin{abstract}
A DEMÁs DE LA IMAGEN DE LA VIRGEN, LAS PIEDRAS DONDE SE ENcuentran petroglifos son otro referente temático de la tradición oral. Estas pinturas están cerca del monasterio, distantes aproximadamente dos kilómetros hacia el oriente por el camino carreteable que conduce a Samacá, cerca del río La Candelaria, donde comienza el ascenso por el camino hacia el alto de Gachaneca.
\end{abstract}

Los petroglifos están sobre dos piedras; la primera, que se observa desde el camino, corresponde a dibujos cuyos trazos son de aproximadamente centímetro y medio entre borde y borde de la concavidad bajo relieve. La segunda es una pintura en la concavidad de una piedra que presenta en su parte inferior una especie de bóveda, donde se encuentra el petroglifo. Esta piedra se conoce como la piedra de la campana. El lugar está situado cerca de un pequeño altiplano, junto a otras piedras con características similares a la última descrita.

En cuanto a los relatos que se tejen en torno a estas piedras, principalmente a la piedra de la campana -pictograma-, es clara la estigmatización de estos objetos de evidencia cultural muisca. 

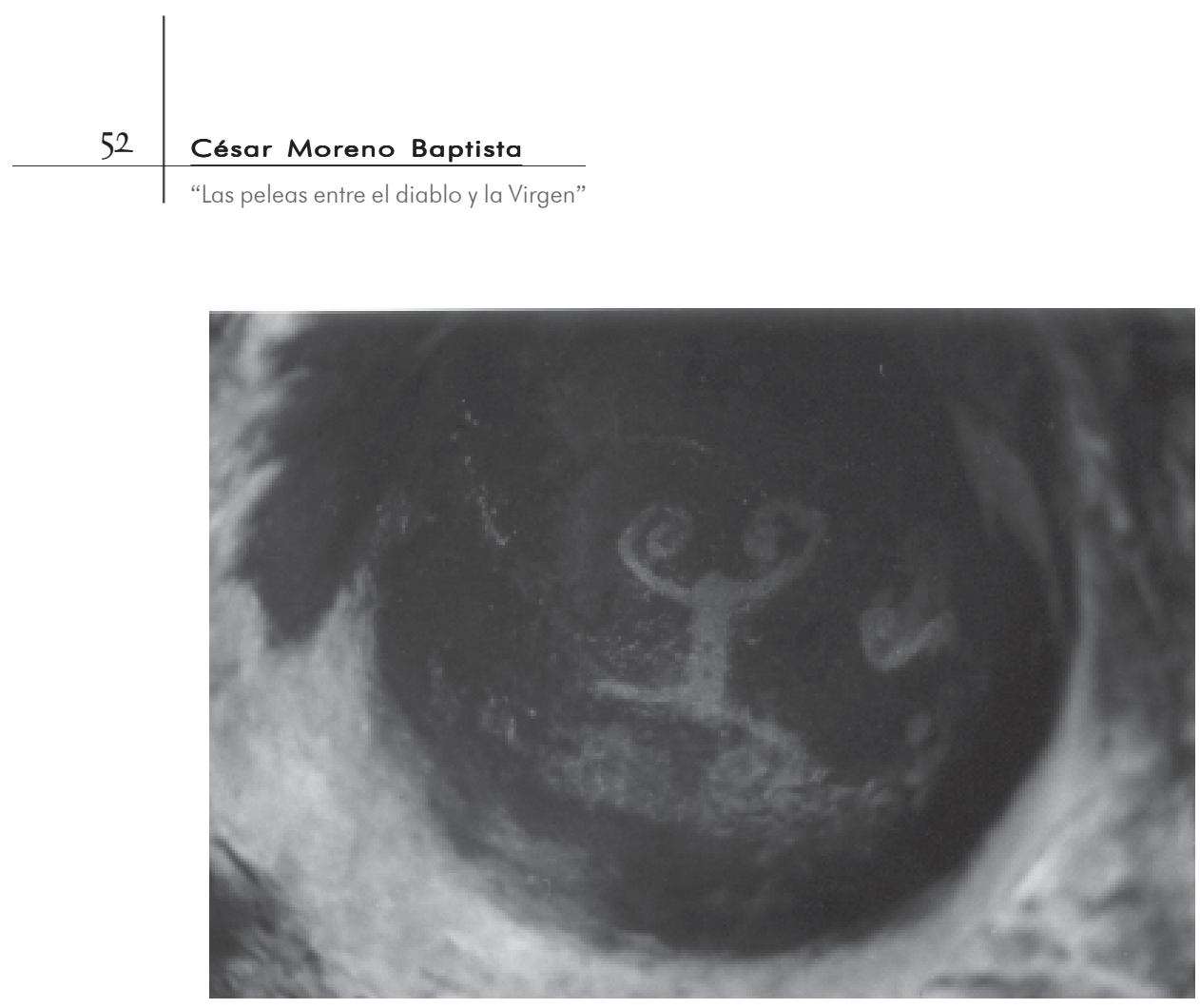

PiedRa de LA CAMPANa (Pictograma)

La llaman la piedra de la campana porque ahí hay una piedra en forma de campana y allá siempre oían tocar, entonces por eso se ha llamado la campana, creo que ahora no, antiguamente sí escuchaban (Álvaro Bautista).

Un día el diablo cogió al santo padre y lo colgó a ahorcarlo, lo colgó (Rafael Bautista).

...alguna vez, según la historia, lo sacó y lo colgó de los pies en el campanario, otra vez le robó la campana y le hacía ruidos por el aire... (Alfredo Casas).

La tradición cuenta que el diablo hizo el último atentado aprovechando un descuido del padre Mateo: se robó la campana de la iglesia y la escondió debajo de una piedra; desde entonces se llama la piedra de la campana, y todos los años, por Semana Santa, la hace sonar. Durante esa época del año es común escuchar cuentos que ridiculizan al diablo, se limita el miedo y se domestica.

Que por ejemplo siempre tocaba para misa la campana, que entonces al diablo no le gustaba que la gente fuera a misa, porque él quería que la gente creyera en él. Entonces el diablo vino a la iglesia y se 


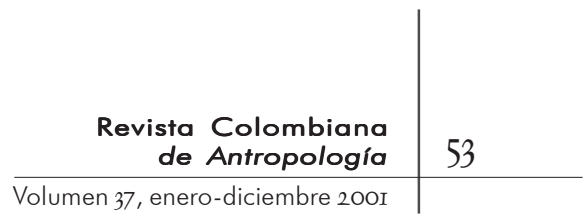

robó la campana y fue y la escondió debajo de esa piedra, pero no se sabe si la sacaron de allá y llevaron pa’otro lado o está ahí (Rocío Bautista).

Otra versión dice que el diablo tiene escondidas allí las campanas que se robó en Furatena -cerro sagrado, en la mitología muisca-.

A lo último las campanas que compraron para ahí el convento que las de ahora son nuevas, que las dañaron y las mandó reformar y yo conozco la campana anterior viejita, compañera de esa campana vieja, dos campanas se le olvidó al padre bendecirlas y el bandido se las llevaba al peñón que hay en Furatena... una peña de esas allá se llevó el diablo la campana en jueves y viernes Santo desde que se pone a tocar un peñón allá jajaja (Querubín Mendieta).

\section{Los desplazamientos de la imagen}

$\mathrm{D}$ ESPUÉS DE ESTABLECIDA LA IMAGEN EN EL LUGAR, LOS RELIGIOSOS Y los pobladores intentaron trasladarla a otros lugares, a otros municipios o santuarios, pero milagrosamente la imagen demostró voluntad propia, resistiéndose al traslado.

El desplazamiento de la imagen introduce una nueva característica a la tradición oral, que establece la correspondencia entre la leyenda y la región en la cual se circunscribe, es decir, aquella que comprende el desierto de La Candelaria. Los actos de transferencia de la imagen por situaciones misteriosas son exclusivos al origen de la misma. Los desplazamientos se hicieron en diferentes direcciones por los caminos del desierto, pero siempre llegaron hasta un sitio desde donde la imagen regresó a su lugar de origen. Estos puntos limítrofes configuran el lugar de culto o lugar del santo patrono.

En la práctica, las actitudes del campesino hacia estos lugares se expresan por medio de gestos rituales; pueden observarse gestos como persignarse al pasar frente a imágenes que se encuentran en esos puntos, quitarse el sombrero en señal de saludo a la entrada del lugar de la Virgen o dejar una cruz a manera de ofrenda en el sitio.

El traslado de regreso de la imagen a su lugar de origen se caracteriza por su consecución misteriosa y luego por su regreso milagroso. La imagen es desplazada a otros lugares para facilitar la 


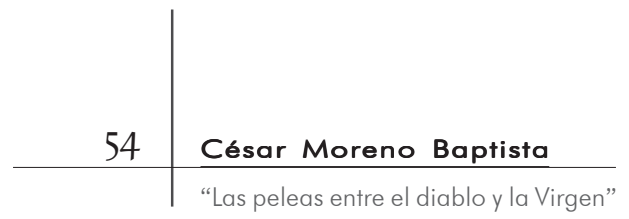

construcción del santuario, ya sea por las condiciones topográficas del terreno, la consecución de los materiales, etcétera; pero por fenómenos naturales o por razones inexplicables ésta no puede pasar de un lugar determinado. Posteriormente, como un acto divino, aparece nuevamente en su lugar de origen. Se demarca así claramente el perímetro del culto en relación con el centro. En otras oportunidades, la imagen es desplazada a grandes distancias pero regresa de nuevo al lugar de aparición; el terreno que no era reconocido y valorado ahora lo es.

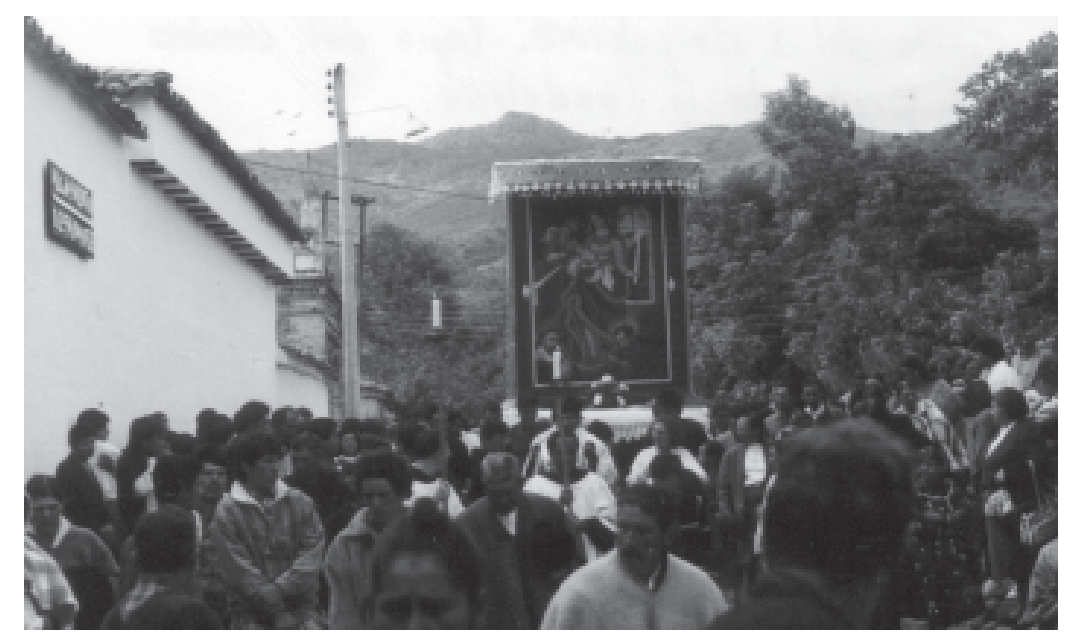

Fiesta DEL 2 DE FEBRERO, CON COPIA DEL CUADRO DE LA VIRGEN DE LA CANDELARIA

La llevaban por la tarde allá, ella no se amañaba y venía p’a su peña. Bueno, después que no se amaña allá y venía p’a su peña, la llevaron p’a Samacá, tampoco alcanzó p'uallá hasta las cruces p’al lado de Samacá y ella no se dejó, ise les puso pesadísima carajo! y no la pudieron llevar, les tocó voltiarla y ahí sí hizo bueno y ella tenía que ser aquí su destino, en el desierto, tenía que hacerle ahí casita, así fue que les toca hacerle el convento ahí (Gabriel Vargas).

La encontraron, ahora sí la veneraron, le rezaron con la idea de llevársela de ahí, que venían a traérsela pa'l pueblo, y tampoco se dejó sacar... (Otilia Jérez).

A la Virgen la pintaron y todo eso, y era llevarla pa' Ráquira, que ya habían fundado el pueblo, que la llevaban en andas hasta Ráquira, que la llevaban en andas hasta el alto, se formaba un viento taluego. Que no, pa'llá no; tenía que ser allí, tenía que ser y hacer la capilla ahí la capilla... (Querubín Mendieta). 


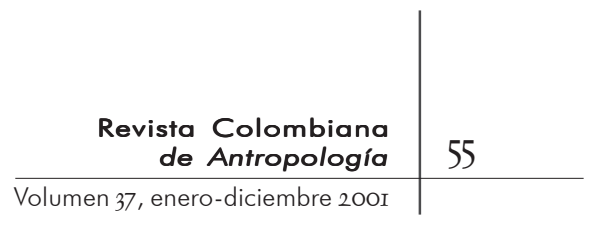

De los relatos anteriores se deduce que los desplazamientos de la imagen hasta determinados lugares, además de trazar los límites patronales y de reconocer y valorar el desierto como lugar de La Candelaria, se dio un proceso de apropiación de la imagen por los habitantes. La imagen de la Virgen se considera la manifestación de poder de un ser sobrenatural, y se constituye en objeto de culto. Tras la ubicación del centro de culto, luego se difunde a otras regiones del país y del continente.

La llevaron pa' Bogotá o se la llevaban, porque querían llevarla pa’ Bogotá del todo y la Virgen se les perdió del camino, por el camino yendo pa' Guachetá, salía a Ubaté y Zipaquirá, por ahí había camino antiguamente... dizque la alcanzaron a llevar unas tres veces hasta Bogotá y la metieron allá en un templo, creo que es que llaman La Candelaria y al otro día no amanecía, y se venían y allí la encontraban (Pedro Valero).

\section{Consideraciones FinAlES}

OS RESULTADOS DEL TRABAJO PERMITEN ESTABLECER QUE EL VÍNCULO entre los campesinos y la geografía del desierto de La Cande-

laria va más allá de la simple relación que se establece entre los habitantes y su medio natural como medio de subsistencia. La relación entre ellos es aún más compleja y se expresa en el plano del simbolismo y las relaciones sociales. Abarca, de una parte, el carácter sagrado que generalmente se atribuye a los lugares cuyos rasgos se caracterizan por la soledad y el aislamiento y, por otra, al discurso sobre las peculiaridades del paisaje que vinculan la naturaleza con un pasado histórico.

En la tradición oral del desierto, el santuario, en tanto lugar de poder, se expresa como un sitio en disputa entre seres sobrenaturales -el diablo y la Virgen-. Existe un conjunto de lugares clave alrededor de los cuales giran los relatos y dichos lugares estarían configurando el escenario de conflicto, que no es otro que el perímetro local donde se rinde culto a la santa patrona. El origen prehispánico del santuario se resignificó con la llegada de los españoles y las creencias populares que se expresan en leyendas, imágenes y tradiciones de carácter explicativo que cumplen la función de justificar la ubicación del santuario católico.

Las leyendas narran acontecimientos de origen que en esencia 


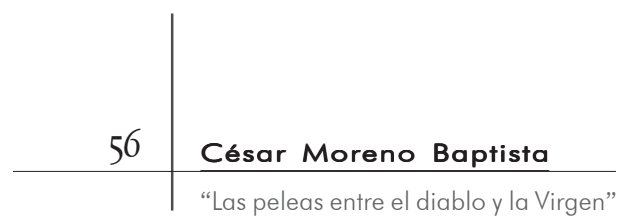

son la expresión del vínculo de la gente del desierto con la imagen de la Virgen o con el ser sobrenatural que esta representa. La leyenda, además, afirma la vinculación de la gente con el lugar; se sugiere así un localismo relacionado con la esencia misma del santuario, en cuanto al origen, devoción, peregrinación y centro de difusión de salud.

También se ha querido señalar que la mentalidad de los campesinos del desierto es el resultado de un largo proceso de síntesis cultural de dos tradiciones diferentes -europea y nativa- decantado en un contexto histórico particular; en esta perspectiva se busca establecer un puente que permita ir y venir entre situaciones del pasado que podemos recrear a partir de los datos historiográficos y el imaginario contemporáneo recreado en la mente de las colectividades actuales.

La historia de la Virgen de La Candelaria como símbolo es parte del proceso de colonización española, en el que el pensamiento occidental satanizó las manifestaciones religiosas de los muiscas, hasta el punto de erigir la imagen cristiana como símbolo legitimador de un nuevo orden social y de una nueva economía sagrada. Al tomar el territorio como referente de tensiones sociales en el plano de las representaciones se establece una relación dialéctica entre territorialidad positiva y negativa, de lo que se comprende que la territorialidad no solo abarca los derechos sobre la utilización productiva del mismo, sino las formas y posibilidades de significarlo.

En esta perspectiva se piensa que aun cuando las leyendas y los mitos populares ya no están dominados por las mentalidades prehispánicas, la literatura oral conserva un lugar preponderante en el reconocimiento de un espacio vital, de una identidad. Como lo señala Dupront (1987), las peregrinaciones a los santuarios son un gesto de búsqueda de lo sagrado; la práctica de visitar santuarios explica la fuerza de las creencias y es testimonio de veracidad. Así es que la riqueza que tienen estos lugares se constituye esencialmente por la revelación, los milagros, las historias legendarias, la tradición y las creencias colectivas, virtudes que les dan una fuerza extraordinaria.

Las peregrinaciones al santuario y las fiestas en homenaje a la Virgen sintetizan continuidades, permanencias, resistencias, adaptabilidad a nuevas condiciones de vida y nuevas formas de memorización. Como lo señala Languebaek (I995) al referirse a 


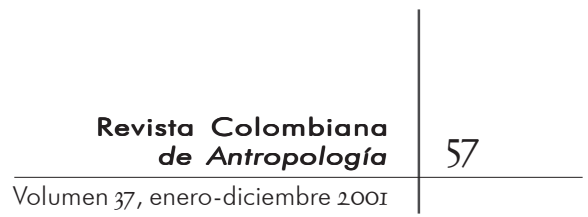

las fiestas en el momento del contacto de americanos y europeos: “...en los bailes y en su música los muiscas hacían memoria de sus antigüedades y en particular de la llegada de los españoles y del sometimiento que implicó para ellos ese acontecimiento”. Languebaek subraya además que “... los españoles veían en las fiestas indígenas un inconveniente para reducir la población al cristianismo y por tal razón ante la persistencia de los indígenas de continuar con sus fiestas y la incapacidad de los españoles para impedirlo, estos últimos terminaron por permitirlas en el escenario público donde ellos pudieran ejercer algún control sobre los comportamientos indígenas". De ahí la cantidad de fiestas patronales a las que asistimos hoy día en Boyacá.

En esta perspectiva cabría la pregunta, ¿por qué las fiestas y las peregrinaciones? La respuesta puede ser que la gente tiene la necesidad de saber dónde se está -social, física y espiritualmente-. De tal suerte que la idea de trazar planos utilizando el territorio como referente conduce a pensar el territorio como algo más que el espacio físico y a tener en cuenta su dimensión significativa.

En fin, se ha tomado el imaginario sobre el paisaje como dispositivo mnemotécnico que ha resistido la amnesia del pasado histórico. Al igual que en el desierto, en todos los pueblos de Boyacá las referencias al diablo son frecuentes. Este personaje, que hizo su aparición con la llegada de los españoles, sigue latente en el imaginario de un pasado, un presente y un futuro.

\section{BIBLIOGRAFÍA}

Adarve, Mauricio. i986. Un siglo de romerías. Cinep. Bogotá.

Ayape, Eugenio de San Agustín. i935. Historia del Desierto de la Candelaria. Escuela Tipográfica Salesiana. Bogotá.

I950. Fundación y noticias de La Provincia de nuestra señora de La Candelaria. Lumen Christi. Bogotá.

Casilimas Rojas, Clara y María López. i982. "Etnohistoria muisca de los Jeques a los doctrineros”. Tesis de grado. Departamento de antropología. Universidad Nacional de Colombia. Bogotá.

Cortés, Vicenta. I960. "Visitas a los santuarios indígenas de Boyacá en 1577”. En Revista Colombiana de Antropología. Volumen IX. Instituto Colombiano de Antropología. Bogotá. 


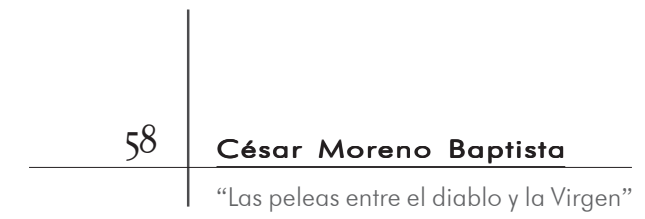

Dupront, Alphonse. 1987. Du sacre. Gallimard. París.

Eliade, Mircea. I983. Imágenes y símbolos. Taurus. Madrid. 1982. Historia de las creencias y de las ideas religiosas. Cristiandad. Madrid.

Fals Borda, Orlando. I979. El hombre y la tierra en Boyacá. Tercer Mundo Editores. Bogotá.

Gnecco, Cristóbal y Martha Zambrano (editores). 2000. Memorias hegemónicas, memorias disidentes. Ican. Bogotá.

GenNEP A., VAn. 1909. La formation de légendes. Ernest Flammarion. París. I98I. Les rites de passages. Picard. París.

GonzÁlez, José Antonio. I989. “Territorio y religión popular en Andalucía oriental”. En Religiosidad popular. Anthropos. Barcelona.

Groot, José Manuel. I893. Historia eclesiástica y civil de la Nueva Granada. Casa Editorial de M. Rivas. Bogotá.

GruZinski, Serge. I990. La guerra de las imágenes. Fondo de Cultura Económica. México.

Halbwachs, Maurice. ig68. La memoire collective. PUF. París. 1964. Les cadres sociaux de la mémoire collective. Alvin Michael. París.

I97I. La topographie légendaire de évangiles en terre sainte. PUF. París.

Hellpach, Willy. 1940. Geopsique: el alma humana bajo el influjo del tiempo y clima, suelo y paisaje. Espasa-Calpe. Madrid.

Hervieu, LÉGer DanièLe. I986. Vers un nouveau cristianisme” Cerf. París. I988. Identités religieuses en Europe. Cerf. París. I993. La religion pour mémoire Cerf. París.

IsAmbert, François. I979. Le Sens du sacré: fête et religion populaire. Minuit. París.

JoDELEt, Denise. 1989. Représentations sociales. PUF. París.

Le Goff, JACQUes. I98I. La naissance du purgatoire. Gallimard. París.

Londoño, EduARdo. I985. “La conquista del Valle de La Laguna”. Informe, semestre de campo. Departamento de antropología. Universidad de los Andes. Bogotá.

Lleras, Roberto. I989. "Historia prehispánica y permanencias culturales”. En Historia y culturas populares. Instituto de Cultura y Bellas Artes de Boyacá. Tunja. 


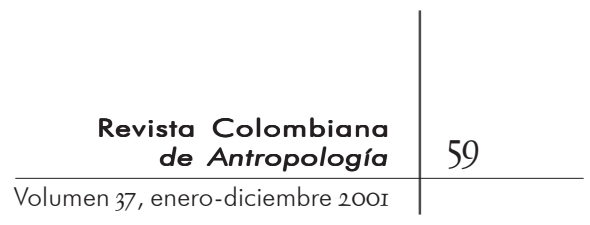

Mateos, F. 1974. "Constituciones sinodales de Santa Fe de Bogotá I576”. En Missionalia Hispánica. T. 31. Dpto. de Misiología Española. Madrid.

Moreno, César. i994. "Mítica y paisaje en el desierto de La Candelaria". Tesis de grado. Departamento de antropología. Universidad Nacional de Colombia. Bogotá.

— 1998. "Modes de penseé et pratiques religieuses chez les paysans du Désert de La Candelaria”. Mémoire DEA "Anthopologie et Sociologie du Politique". Universite Paris VIII.

OcAmpo LóPEz, JAVIER. I98I. "Las haciendas y la propiedad territorial Boyacá”. En El Relator de Semana. Ráquira.

Pinzón, Carlos y Rosa SuÁrez. i992. Las mujeres lechuza. Instituto Colombiano de Antropología-Cerec. Bogotá.

Poole, Deborah. I982. "Los santuarios religiosos en la economía regional andina". En Allpachis Phuturina. XVI n ${ }^{\circ}$ I9. Instituto Pastoral Andina. Quito.

Ricoeur, Paul. 1988. Le temps raconte. Editions du Seuil. París.

RAPAPPORT, JOANNE. 2000. "Espacio y evangelización”. Documento inédito.

Reichel-Dolmatoff, Gerardo. I975. "Templos kogi: introducción al simbolismo y a la astronomía del espacio sagrado". En Revista Colombiana de Antropología. Volumen XIX. Instituto Colombiano de Antropología. Bogotá.

Simón, Fray Pedro. I98I. Noticias historiales de la conquista de tierra firme en las Indias Occidentales. Tomo III. Banco de la República. Bogotá.

Sotomayor, María Lucía. I996. "Organización económica de las cofradías, siglo XVIII". En Boletín Museo del Oro. $\mathrm{N}^{\circ}$ 40. Bogotá.

Toboada, Diez María. i989. "La significación de los santuarios". En Religiosidad popular. Anthropos. Barcelona.

VAnsina, Jan. 1968. La tradición oral. Labor. Barcelona.

Velasco, Maillo. 1989. Las leyendas de hallazgos y apariciones. Anthropos. Barcelona.

Wachetel, Nathan. 1999. "Memoria e historia". En Revista Colombiana de Antropología. Vol. 35. ICAN. Bogotá.

Wolf, ERIC. I97I. Los campesinos. Labor. Barcelona.

Zambrano, Vladimir. I993. Hombres de páramo y montaña. ICAN. Bogotá.

I994 “Las Vírgenes remanecidas”. En Memorias de simposio internacional de cultura y salud. Cerec. Bogotá. 